\title{
Estimation of heritability and genetic advance in $F 3$ populations of wheat
}

\author{
Muhammad Manzoor Ul Haq, Ghulam Hassan, Fakharuddin*, Zeeshan \\ Khalil, Naveed Iqbal, Ubaid Ullah and Ataullah \\ Department of Plant Breeding and Genetics, The University of Agriculture, Peshawar, Khyber Pakhtunkhwa- \\ Pakistan \\ *Corresponding author's email: fakharpbg@gmail.com \\ Citation \\ Muhammad Manzoor Ul Haq, Ghulam Hassan, Fakharuddin, Zeeshan Khalil, Naveed Iqbal, Ubaid Ullah and \\ Ataullah. Estimation of heritability and genetic advance in $\mathrm{F}_{3}$ populations of wheat. Pure and Applied Biology. Vol. \\ 5, Issue 4, pp773-781. http://dx.doi.org/10.19045/bspab.2016.50097
}

\begin{tabular}{llll}
\hline \hline Received: 28/03/2016 & Revised: 12/07/2016 & Accepted: 20/07/2016 & Online First: 00808/2016 \\
\hline
\end{tabular}

\section{Abstract}

Knowledge of inheritance of important plant traits is the basis of selection program. To check genetic variability and transmission pattern of essential plant characters, a research was conducted comprising 8 parents and 8 cross combinations at the research fields of The University of Agriculture, Peshawar, during 2014-15. The experiment was laid out using randomized complete block design with three repetitions. Data were recorded on yield and other important plant traits. Sufficient variations were detected for all the studied traits showing adequate scope of crop improvement. Traits like flag leaf area (0.82), plant height (0.81), fertile tillers plant ${ }^{-1}$ (0.83), biological yield (0.90), grains $\operatorname{spike}^{-1}(0.93)$ and grain yield plant ${ }^{-1}(0.90)$ manifested high heritability estimates with high genetic advance (14.15, 13.48, 4.57, 28.28, 21.64 and 15.7, respectively) suggested that they were under additive gene control. We recommend Tatara $\times$ Janbaz, AUP-5008 × Janbaz, Saleem-2000 × Siren, Saleem-2000 × Janbaz and AUP-5008 $\times$ Siren to be further assessed in cultivar development programs.

Keywords: Wheat (Triticum aestivum L.); F3 populations; Variability; Heritability; Genetic

\section{advance}

\section{Introduction}

Wheat is not only the world's main cereal crop but also a staple food item in many parts of the world. It is the member of family Poaceae also known as Graminae. Wheat is believed to be the first cereal which has ever been domesticated by human beings. Unlike wheat counterparts, its ability of self-pollination and simplicity has made it more attractive to many breeders who have developed many varieties merely by selection. The success of any breeding program could only be realized by effective selection. The wider the scale of heritable differences the effective will be the selection. Therefore, information regarding heredity of important plant traits is crucial to proceed in the right direction [1]. The values of heritability can serve in measuring the degree of association between parents and their offspring [2]. High heritability estimates associated with high genetic advance can increase the chances of success from selection in cultivar development. High yield is one of the prime objectives in any breeding program. Since yield is a quantitative and complex trait, therefore the knowledge of genetic expression of all its 
associated components is prerequisite for higher yield. Extensive research work is being going on to concentrate the desirable genes in the existing germplasm to achieve the goal of high productivity. Unfortunately, fixable (additive) genes are lesser in proportion than non-fixable (non-additive or epistatic) genes therefore, to utilize both, breeding methods like bi-parental crossing is usually suggested to improve the grain yield and other related traits [3]. Present research work was therefore designed to assess the gene flow and heritability in specific wheat crosses. This information will help in planning effective breeding strategy to select hybrids or potential segregants with desired traits in succeeding generations.

\section{Materials and methods}

Present research was carried out in the research fields of The University of Agriculture, Peshawar, Pakistan during 2014-15. The plant material consisted eight parents and their eight $\mathrm{F}_{3}$ progenies (Table 1). Seeds of parental lines along with their selected $\mathrm{F}_{3}$ crosses were space planted in randomized complete block design with three replicates. Each plot consists of three rows per entry of $3 \mathrm{~m}$ row length, row to row and plant to plant spacing was kept at $30 \mathrm{~cm}$ and $15 \mathrm{~cm}$, respectively. Standard cultural practices were carried throughout the growing season.

Table 1. List of genotypes wheat genotypes including 8 parents and 8 F3 populations

\begin{tabular}{|c|l|l|c|l|}
\hline S \# & Parents & & S \# & F 3 populations \\
\hline 1 & Janbaz & $($ AUP) & 9 & Barsat $\times$ Pirsabak-2005 \\
\hline 2 & Siren & $($ AUP) & 10 & Saleem-2000 $\times$ Pirsabak-2005 \\
\hline 3 & Fakhr-e-Sarhad & $($ NIFA) & 11 & Tatara $\times$ Fakhr-e-Sarhad \\
\hline 4 & Pirsabak-2005 & $($ CCRI) & 12 & AUP-5008 $\times$ Fakhr-e-Sarhad \\
\hline 5 & AUP-5008 & $($ AUP) & 13 & Barsat $\times$ Siren \\
\hline 6 & Tatara & $($ NIFA) & 14 & Saleem-2000 $\times$ Siren \\
\hline 7 & Saleem-2000 & $($ NIFA) & 15 & AUP-5008 $\times$ Janbaz \\
\hline 8 & Barsat & $($ NIFA) & 16 & Tatara $\times$ Janbaz \\
\hline
\end{tabular}

\section{Statistical analyses}

Field data obtained for various traits were subjected to analysis of variance technique to test the significance of each trait using computer software Statistix ver. 8.1. Means were separated using Least Significant Difference (LSD) test.

\section{Heritability and genetic advance}

Broad sense heritability and genetic advance was calculated for important characters using formula's suggested by Mahmud and Kramer [4] revised by Allard [5].

\section{Results and discussion}

\section{Analysis of variance}

Mean square values manifested considerable amount of variation among the tested lines for flag leaf area, plant height, fertile tillers plant $^{-1}$, biological yield, grains spike $^{-1}$, hundred grains weight and grain yield, whereas, parents vs. $\mathrm{F}_{3}$ populations displayed significant variation for all the studied traits except flag leaf area, plant height and grain yield (Table 2) suggesting the lines are segregating and that there is enough amount of variation present among the genotypes for the said characters. Our results were confirmed by earlier scientists like Uddin et al., Waqas et al. and Azam et al. $[6,8]$, who observed significant variation in their wheat segregating populations.

\section{Flag leaf area}

Flag leaf area is an important yield contributing character particularly in wheat. The broader flag leaf offers more surface area for the sunlight to carry out photosynthesis and in turn the plant fixes 
more dry matter in the form of proteins and carbohydrates. Thus greater flag leaf area would result in broader and heavier grains. Overall, genotypes had an average value ranged between 31.4 and $48.7 \mathrm{~cm}^{2}$. Among parental genotypes, minimum leaf area (31.4 $\mathrm{cm}^{2}$ ) was recorded for AUP-5008, whereas, maximum leaf area $\left(48.7 \mathrm{~cm}^{2}\right)$ was displayed by genotype Pirsaak-2005. Among $\mathrm{F}_{3}$ populations, mean values ranged from 32.9 to 44.4 for AUP $5008 \times$ Siren and AUP $5008 \times$ Janbaz, respectively. In parental genotypes, variances regarding leaf area varied from 7.91 (Janbaz) to 41.52 (AUP5008). Minimum variation (28.08) was observed for genotype AUP-5008 $\times$ Siren, whereas, maximum variation (95.95) was recorded for Saleem-2000 $\times$ Siren among $\mathrm{F}_{3}$ populations (Table 4). Moderate to high broad sense heritability ( 0.30 to 0.82$)$ and genetic advance (3.69 to 14.15) was observed in $\mathrm{F}_{2}$ populations for flag leaf area. Genotype Saleem-2000 × Siren exhibited high broad sense heritability (0.82) together with high genetic advance (14.15) for flag leaf area indicate the presence of additive genes hence, selection would be effective in early generations, whereas, low heritability (0.30) and low genetic advance was displayed by genotype Tatara $\times$ Janbaz (Table 4) suggesting the slow transmission of genes in this trait. Our results are supported by the outcomes of Hussain et al. and Rashid et al. $[9,10]$.

Table 2. Mean squares value for different characters evaluated during 2014-15

\begin{tabular}{|l|c|c|c|c|c|c|c|c|}
\hline SOV & DF & $\begin{array}{c}\text { Flag leaf } \\
\text { area }\end{array}$ & $\begin{array}{c}\text { Plant } \\
\text { height }\end{array}$ & $\begin{array}{c}\text { Fertile } \\
\text { tillers } \\
\text { plant }\end{array}$ & $\begin{array}{c}\text { Grains } \\
\text { spike }\end{array}$ & $\begin{array}{c}\text { 100-grain } \\
\text { weight }\end{array}$ & $\begin{array}{c}\text { Biological } \\
\text { yield }\end{array}$ & $\begin{array}{c}\text { Grain } \\
\text { yield }\end{array}$ \\
\hline Reps & 2 & 28.36 & 29.62 & $5.90^{* *}$ & 4.34 & 0.03 & 71.92 & 3.54 \\
\hline Genotypes & 15 & $60.83^{* *}$ & $77.36^{* *}$ & $4.11^{* *}$ & $72.96^{* *}$ & $0.35^{* *}$ & $116.32^{* *}$ & $18.79^{* *}$ \\
\hline Parents & 7 & $99.17^{* *}$ & $101.21^{* *}$ & $3.16^{* *}$ & $67.08^{* *}$ & $0.36^{* *}$ & $95.07^{*}$ & $24.55^{* *}$ \\
\hline F $\mathbf{3}$ Populations $^{*}$ & 7 & $31.14^{* *}$ & $64.52^{*}$ & $5.22^{* *}$ & $78.41^{* *}$ & $0.29^{*}$ & $111.36^{*}$ & $14.26^{*}$ \\
\hline P vs. F 's $^{\text {3 }}$ & 1 & 0.24 & 0.35 & $3.01^{*}$ & $76.00^{* *}$ & $0.77^{* *}$ & $299.81^{* *}$ & 10.19 \\
\hline Error & 30 & 9.65 & 23.20 & 0.48 & 3.47 & 0.12 & 36.5 & 4.95 \\
\hline CV (\%) & & 7.91 & 5.23 & 8.15 & 2.72 & 10.66 & 11.04 & 10.12 \\
\hline
\end{tabular}

$*, * *=$ Significant at $5 \%$ and $1 \%$ probability level respectively

\section{Plant height}

Breeders are mostly interested in semi dwarf plants due to their positive response to lodging and other inputs (like fertilizers \& irrigation). Most researchers suggested that plant height for wheat ideotype ranged between 90 and $100 \mathrm{~cm}$. Overall, genotypes performance for plant height varied from 84.0 to $100.2 \mathrm{~cm}$ for genotype Barsat (parent) and genotype Pirsabak-2005 (parent) (Table 3), respectively. Whereas, $\mathrm{F}_{3}$ populations varied from 86.1 to $98.1 \mathrm{~cm}$, short statured plants were exhibited by Tatara $\times$ Janbaz, whereas, Barsat $\times$ Siren displayed plants with tall stature (Table 3). Minimum variation (10.15) was revealed by parental genotype Janbaz, while maximum variation (33.85) was observed for genotype Barsat. In $\mathrm{F}_{3}$ populations minimum variation was observed (30.72) for Tatara $\times$ Janbaz, whereas, maximum variation (88.95) for cross Tatara $\times$ Siren (Table 4). $\quad F_{3}$ populations displayed low to high broad sense heritability ( 0.27 to 0.81$)$, whereas, moderate to high genetic advance (3.04 to 13.48) for plant height. High broad sense heritability and high genetic advance was recorded for genotype Tatara $\times$ Siren, which is a sign of additive gene actions in controlling of this trait. Whereas, low heritability coupled (0.27) with low genetic advance (3.04) was observed in genotype 
AUP-5008 $\times$ Janbaz, for plant height (Table 4). These findings are in conformity with the results of Hussain et al. [9], who found that plant height was controlled by additive gene actions in their segregating population.

\section{Tillers plant ${ }^{-1}$}

Productive tillers plant $^{-1}$ is an important yield component as it is directly correlated with number of spikes plant ${ }^{-1}$. Thus, increase in tillers plant ${ }^{-1}$ could ensure greater yield. Mean data of genotypes regarding fertile tillers plant ${ }^{-1}$ ranged between 7 and 10 (for Janbaz and AUP-5008, respectively). Whereas, among segregating population, maximum number of tillers were recorded for Aup-5008 $\times$ Janbaz and Barsat $\times$ Siren, while minimum number of tillers were displayed by Tatara $\times$ Janbaz (Table 3). Among parental genotypes, variances varied from 1.30 to 2.65. Minimum variation was observed for Barsat (1.30), whereas maximum variation was recorded for parent Janbaz (2.65). Among $\mathrm{F}_{3}$ populations minimum variation (4.32) was observed for AUP-5008 $\times$ Janbaz, whereas, maximum variation was recorded (9.72) for genotype Saleem-2000 × Janbaz (Table 4). Low to high broad sense heritability and genetic advance among $\mathrm{F}_{3}$ populations were observed which ranged from 0.25 to 0.83 and 0.90 to 4.57, respectively. High heritability (0.83) and moderate genetic advance (4.57) was observed for Saleem$2000 \times$ Janbaz, whereas, minimum heritability $(0.25)$ coupled with low genetic advance (0.90) was observed for AUP-5008 $\times$ Janbaz, respectively (Table 4).

High heritability with low genetic advance hinting toward non-additive gene effects in the transmission of this trait. Hence, selection in early generations could be deceptive. Predominance of non-additive gene action could be exploited in heterosis breeding. Almost same results were reported by Rashid et al. and Singh and Upadhyay [10, 11], who observed low to high heritability among wheat genotypes for the said parameter, while our results are contradictory to the results of Ijaz and Samiullah [12], who estimated high heritability and genetic advance for tillers plant $^{-1}$ among their wheat genotypes.

\section{Grains spike ${ }^{-1}$}

Grains spike ${ }^{-1}$ is also an important yield trait in wheat. A greater number of grains spike ${ }^{-1}$ would only be useful if they are healthy and not shrunken having adequate weight. Greater number of shriveled and poor grains could dramatically shrink the hopes of high production. Genotypes mean performance for grains spike $^{-1}$ ranged from 60.1 to 77 . Maximum grains spike ${ }^{-1}$ (77) was recorded in the cross combination of $\mathrm{F}_{3}$ population, Aup-5008 $\times$ Janbaz, whereas, the least number of grains spike ${ }^{-1}$ was recorded for parental genotype Siren (Table 3). In $\mathrm{F}_{3}$ population genotype Saleem-2000 $\times$ Janbaz indicated highest variability (176.43) for grains spike ${ }^{-1}$. High heritability (0.93) with maximum genetic advance (21.64) was also observed for Saleem-2000 $\times$ Janbaz followed by Tatara $\times$ Siren 0.90 and 17.98 respectively. Similarly, genotype AUP-5008 $\times$ Janbaz exhibited moderate heritability (0.65) coupled with high genetic advance (13.22) (Table 4). A fairly high heritability and genetic advance of all the combinations for grains spike ${ }^{-1}$ indicated that progenies of these crosses could be used for improving grains spike $^{-1}$. These findings are in line with the outcome of Waqas et al. and Hussain et al. [7, 9], who estimated high heritability and genetic advance in their wheat germplasm.

\section{0-grain weight}

Data regarding mean values for 100-grain weight ranged from 2.51 (Barsat $\times$ Siren) to $3.80 \mathrm{~g}$ (Pirsabak-2005). Among parental genotypes 100-grain weight ranged from 2.64 to 3.80 for Janbaz and Pirsabak-2005 respectively, while in segregating populations, grain weight ranged from 2.51 
g $($ Barsat $\times$ Siren) to 3.51 (Saleem-2000 $\times$ Siren). Variation among genotypes ranged from 0.10 to 0.23 for 100 -grain weight. Minimum variation (0.10) was observed in parental genotype Pirsabak-2005, while the maximum variation (0.23) was recorded for genotype Saleem-2000. In $\mathrm{F}_{3}$ populations minimum variation $(0.21)$ was observed in genotype Barsat $\times$ Siren, whereas, maximum variation (0.59) was recorded for genotype Saleem-2000 $\times$ Janbaz (Table 4). Heritability magnitude and genetic advance varied from 0.33 to 0.71 and 0.30 to 0.96 , respectively. Maximum heritability (0.71) accompanied with low genetic advance (0.96) was calculated for genotype Saleem$2000 \times$ Janbaz suggesting the predominance of non-additive gene action, whereas, minimum heritability (0.33) and genetic advance (0.30) was observed for cross of AUP-5008 $\times$ Janbaz (Table 4) implying role of environment in the inheritance of this trait. Jan et al. [13] also observed high heritability coupled with low genetic advance among their wheat genotypes.

\section{Biological yield plant ${ }^{-1}$}

Biological yield plant $^{-1}$ ranged from $42.7 \mathrm{~g}$ to $64.3 \mathrm{~g}$. Maximum biological yield (59.1 g) among parental genotypes were recorded for AUP-5008, whereas, genotype Janbaz showed minimum value $(42.7 \mathrm{~g})$ for biological yield. Among $\mathrm{F}_{3}$ populations AUP-5008 $\times$ Janbaz showed maximum biological yield (64.3 g), whereas, Barsat $\times$ Janbaz displayed minimum biological yield (44.2). Among parents, minimum variation (20.43) was observed for Janbaz, while maximum variation (45.61) was observed for Saleem-2000. Among $\mathrm{F}_{3}$ populations minimum variation was observed (179.32) for Tatara $\times$ Janbaz, whereas maximum (320.32) for cross Tatara $\times$ Siren (Table 4). In $F_{3}$ population broad sense heritability and genetic advance for biological yield ranged from 0.70 to 0.90 and 20.03 to 28.28, respectively. Maximum heritability (0.90) and genetic advance (28.28) for was recorded for Saleem-2000 × Janbaz, whereas, minimum heritability (0.70) and genetic advance (20.17) was observed for cross combination AUP-5008 $\times$ Janbaz (Table 4). All crosses showed high heritability estimates with suitable genetic advance indicating adequate possibility of improvement could be expected from selection. Our results are in line with those obtained by Kumar et al. [14], who observed high broad sense heritability coupled with high genetic advance for biological yield among wheat genotypes, whereas, contradictory results have been reported by Khalid et al. [15] in their wheat genotypes. 
Haq et al.

Table 3. Mean values of 6 characters studied during 2014-15

\begin{tabular}{|c|c|c|c|c|c|c|c|}
\hline Genotypes & $\begin{array}{l}\text { Flag } \\
\text { leaf } \\
\text { area }\end{array}$ & $\begin{array}{c}\text { Plant } \\
\text { height }\end{array}$ & $\begin{array}{c}\text { Fertile } \\
\text { tillers }\end{array}$ & $\begin{array}{l}\text { Grains } \\
\text { spike }^{-1}\end{array}$ & $\begin{array}{l}\text { 100- } \\
\text { Grians } \\
\text { weight }\end{array}$ & $\begin{array}{c}\text { Biological } \\
\text { yield }\end{array}$ & $\begin{array}{c}\text { Grain } \\
\text { yield }\end{array}$ \\
\hline \multicolumn{8}{|c|}{ Parents } \\
\hline Janbaz & 42.07 & 96.97 & 8 & 72 & 2.64 & 42.72 & 19.70 \\
\hline Siren & 35.36 & 92.60 & 8 & 60 & 3.47 & 56.28 & 26.07 \\
\hline Fakhr-e-Sarhad & 40.46 & 85.33 & 10 & 73 & 3.04 & 46.16 & 25.86 \\
\hline Pirsabak-2005 & 48.74 & 100.20 & 10 & 63 & 3.80 & 52.43 & 20.43 \\
\hline AUP-5008 & 31.42 & 93.07 & 10 & 68 & 3.38 & 59.13 & 19.09 \\
\hline Tatara & 44.72 & 97.00 & 8 & 64 & 3.43 & 57.67 & 24.27 \\
\hline Saleem-2000 & 37.23 & 88.87 & 8 & 72 & 3.29 & 51.25 & 23.16 \\
\hline Barsat & 34.63 & 84.00 & 9 & 66 & 3.47 & 52.23 & 20.66 \\
\hline \multicolumn{8}{|c|}{$F_{3}$ population } \\
\hline $\begin{array}{l}\text { AUP-5008 } \\
\times \text { Janbaz }\end{array}$ & 44.37 & 87.93 & 10 & 77 & 3.82 & 64.34 & 26.22 \\
\hline Tatara $\times$ Janbaz & 39.64 & 86.13 & 7 & 73 & 3.14 & 60.54 & 20.63 \\
\hline $\begin{array}{l}\text { Saleem-2000 } \times \\
\text { Janbaz }\end{array}$ & 39.09 & 94.93 & 8 & 66 & 2.86 & 56.19 & 20.12 \\
\hline Barsat $\times$ Janbaz & 37.31 & 94.27 & 8 & 63 & 3.13 & 44.16 & 19.61 \\
\hline AUP-5008 $\times$ Siren & 32.90 & 92.00 & 9 & 67 & 2.99 & 54.86 & 23.56 \\
\hline Tatara $\times$ Siren & 40.24 & 86.73 & 7 & 73 & 2.96 & 60.06 & 20.87 \\
\hline $\begin{array}{l}\text { Saleem- } 2000 \times \\
\text { Siren }\end{array}$ & 40.22 & 96.53 & 7 & 72 & 3.51 & 60.78 & 19.71 \\
\hline Barsat $\times$ Siren & 39.72 & 98.13 & 10 & 67 & 2.51 & 56.94 & 21.89 \\
\hline Mean & 39 & 92 & 9 & 68 & 3 & 55 & 22 \\
\hline LSD $_{(0.05)}$ & 5.40 & 8.38 & 1.21 & 3.24 & 0.58 & 10.51 & 3.87 \\
\hline
\end{tabular}


Table 4. Variance, heritability and genetic advance for 6 characters studied during 2014-15

\begin{tabular}{|c|c|c|c|c|c|c|c|c|c|c|c|c|c|c|c|c|c|c|c|c|c|}
\hline \multirow[t]{2}{*}{ Genotypes } & \multicolumn{3}{|c|}{ Flag leaf area } & \multicolumn{3}{|c|}{ Plant height } & \multicolumn{3}{|c|}{ Fertile tillers plant $^{-1}$} & \multicolumn{3}{|c|}{ Biological yield } & \multicolumn{3}{|c|}{ Grains spike $^{-1}$} & \multicolumn{3}{|c|}{ 100-grain weight } & \multicolumn{3}{|c|}{ Grain yield plant $^{-1}$} \\
\hline & Var. & $\mathbf{h}^{2}$ & GA & Var. & $\mathbf{h}^{2}$ & GA & Var. & $\mathbf{h}^{2}$ & GA & Var. & $\mathbf{h}^{2}$ & GA & Var. & $\mathbf{h}^{2}$ & GA & Var. & $\mathbf{h}^{2}$ & GA & Var. & $\mathbf{h}^{2}$ & GA \\
\hline \multicolumn{22}{|c|}{ Parents } \\
\hline Janbaz & 41.52 & & & 10.15 & & & 1.3 & & & 20.43 & & & 11 & & & 0.13 & & & 12.3 & & \\
\hline Siren & 11.87 & & & 21.56 & & & 1.6 & & & 35.4 & & & 15.9 & & & 0.12 & & & 10.4 & & \\
\hline Fakhr-e-Sarhad & 25.95 & & & 14.11 & & & 1.6 & & & 27.82 & & & 11.2 & & & 0.15 & & & 8.32 & & \\
\hline Pirsabak-2005 & 35.07 & & & 23.19 & & & 1.8 & & & 27.12 & & & 18.1 & & & 0.098 & & & 9.87 & & \\
\hline AUP-5008 & 7.91 & & & 21.30 & & & 2.5 & & & 24.76 & & & 17 & & & 0.12 & & & 9.32 & & \\
\hline Tatara & 29.99 & & & 12.95 & & & 1.8 & & & 35.55 & & & 16.9 & & & 0.11 & & & 10.1 & & \\
\hline Barsat & 19.34 & & & 33.85 & & & 2.7 & & & 40.43 & & & 16.3 & & & 0.12 & & & 11.7 & & \\
\hline \multicolumn{22}{|c|}{$F_{3}$ Populations } \\
\hline AUP-5008 $\times$ Janbaz & 57.39 & 0.63 & 8.38 & 40.21 & 0.27 & 3.04 & 4.32 & 0.25 & 0.90 & 270.2 & 0.697 & 20.17 & 135 & 0.65 & 13.29 & 0.27 & 0.33 & 0.305 & 85.3 & 0.67 & 10.89 \\
\hline Tatara $\times$ Janbaz & 50.77 & 0.30 & 3.82 & 30.72 & 0.63 & 6.11 & 6.32 & 0.76 & 3.35 & 179.3 & 0.85 & 20.03 & 130 & 0.9 & 18.06 & 0.23 & 0.48 & 0.405 & 69.4 & 0.84 & 12.3 \\
\hline Saleem-2000 $\times$ Janbaz & 46.69 & 0.31 & 3.74 & 75.12 & 0.76 & 11.64 & 9.72 & 0.83 & 4.57 & 316.2 & 0.903 & 28.28 & 176 & 0.93 & 21.64 & 0.59 & 0.71 & 0.956 & 84.3 & 0.88 & 14.2 \\
\hline Barsat $\times$ Janbaz & 38.78 & 0.61 & 6.68 & 49.21 & 0.45 & 5.57 & 5.94 & 0.65 & 2.79 & 280.4 & 0.865 & 25.5 & 139 & 0.88 & 18.31 & 0.22 & 0.45 & 0.375 & 78.7 & 0.86 & 13.4 \\
\hline AUP-5008 $\times$ Siren & 28.08 & 0.65 & 6.11 & 76.12 & 0.72 & 11.03 & 8.91 & 0.78 & 4.08 & 294.5 & 0.899 & 27.17 & 88.1 & 0.81 & 13.44 & 0.37 & 0.68 & 0.723 & 98.3 & 0.9 & 15.7 \\
\hline Tatara $\times$ Siren & 30.44 & 0.38 & 3.69 & 88.95 & 0.81 & 13.48 & 7.41 & 0.77 & 3.69 & 320.3 & 0.889 & 28.01 & 135 & 0.88 & 17.97 & 0.34 & 0.66 & 0.679 & 88.7 & 0.88 & 14.7 \\
\hline Saleem-2000 $\times$ Siren & 95.95 & 0.82 & 14.15 & 47.78 & 0.46 & 5.56 & 8.64 & 0.79 & 4.09 & 314.1 & 0.872 & 27.2 & 98.3 & 0.84 & 14.65 & 0.28 & 0.41 & 0.379 & 96.5 & 0.9 & 15.6 \\
\hline
\end{tabular}




\section{Grain yield}

Grain yield is the prime objective of plant breeders. Grain yield plant ${ }^{-1}$ among genotypes ranged from $19.1 \mathrm{~g}$ to $26.2 \mathrm{~g}$. Among parental genotypes yield varied from 19.1 (AUP-5008) to $26.1 \mathrm{~g}$ (Fakhr-eSarhad). Whereas, $F_{3}$ populations ranged between $19.6 \mathrm{~g}$ and $25.9 \mathrm{~g}$ for cross combination Barsat $\times$ Janbaz and AUP-5008 $\times$ Janbaz, respectively (Table 3 ). Among parental genotypes, variances varied from 8.32 to 12.30 . Minimum variation was observed for Fakhr-e-Sarhad (8.32), whereas maximum variation was recorded for Janbaz (12.30). Among $\mathrm{F}_{3}$ populations minimum variation was observed (69.43) for Tatara $X$ Janbaz, whereas maximum variation (98.33) for AUP-5008 $\times$ Siren (Table 4). Broad sense heritability and genetic advance among $\mathrm{F}_{3}$ populations ranged from 0.67 to 0.90 and 10.89 to 15.7 respectively, indicating the presence of fixable genes hence selection in early generation would be fruitful. Maximum broad sense heritability and genetic advance for grain yield plant ${ }^{-1}$ were observed in genotype Saleem-2000 $\times$ Siren (0.90 and 15.6 respectively) and AUP$5008 \times$ Siren (0.90 and 15.7 respectively), whereas, minimum heritability (0.67) and genetic advance (10.89) were observed for AUP-5008 × Janbaz (Table 4). Similar results were also stated by Waqas et al., Hussain et al., Ijaz and Samiullah and Baloch et al. $[7,9,12,16]$ in their study.

\section{Conclusions}

All genotypes exhibited significant difference for the studied traits. Overall, cross combination Tatara $\times$ Janbaz, AUP$5008 \times$ Janbaz, Saleem-2000 $\times$ Siren, Saleem $\times$ Janbaz and AUP-5008 $\times$ Siren displayed maximum fertile tillers plant ${ }^{-1}$, biological yield, Grains spike ${ }^{-1}$, and 100grain weight. The mentioned crosses manifested high heritability and genetic advance suggesting adequate improvement from selection could be expected in early generations. These crosses are recommended for further testing in cultivar development program to obtain high productivity.

\section{Authors' contributions}

Conceived and designed the experiments: $\mathrm{G}$ Hassan, Performed the experiments: MMU Haq, Analyzed the data: U Ullah \& Ataullah Contributed reagents/ materials/ analysis tools: Z Khalil \& N Iqbal, Wrote the paper: Fakharuddin.

\section{References}

1. Khan SA, Saleem I \& Ali Z (2003). Heritability of various morphological traits in wheat. Int J Agri Biol 5(2): 138140.

2. Memon S, Qureshi MUD, Ansari BA and Sial MA (2007). Genetic heritability for grain yield and its related characters in spring wheat (Triticum aestivum L.). Pak J Bot, 39(5), 1503-1509.

3. Shekhawat US, Prakash V \& Bhardwaj RP (2006). Inheritance of grain yield and tillers per plant in wheat (Triticum aestivum L.). The Ind Genet Plant Breed. 66(1):16-18

4. Mahmud I \& Kramer HH (1951). Segregation for yield, height and maturity following a soybean cross. Agron J, 43: 605-609.

5. Allard RW (1960). Principles of plant breeding. John Wiley and Sons Inc. New York.

6. Uddin F, Mohammad $\mathrm{F}$ \& Ahmed $\mathrm{S}$ (2015). Genetic Divergence in wheat Recombinant Inbred lines for yield and yield components. Am-Euras J Agric \& Environ Sci, 15(9): 1854-1859.

7. Waqas M, Faheem M, Khan AS, Shehzad M \& Ansari MAA (2014). Estimation of heritability and genetic advance for some yield traits in eight F2populations of wheat (Triticum aestivum L). Sci Lett 2(2): 43-47.

8. Azam SM, Muhammad, Ahmad I, Khalil IH, Jadoon SA \& Nasim A (2013). 
Divergence in F3 segregating bread wheat populations. Int J Agric App Sci 13(03):16.

9. Hussain F, Rafiq M, Iqbal Z, Iqbal J \& Chowdhry MA (2013). Estimates of heritability and genetic advance for grain yield and its components in different segregating populations of wheat. $J$ Agric Res, 51(4):349-60.

10. Rashid J, Anwar F, Abdullah \& Khaliq I (2013). Estimation of heritability for some polygenic traits in hexaploid wheat. Int J Agri Crop Sci 6(8): 458-463.

11. Singh B \& Upadhyay PK (2013). Genetic variability, correlation and path analysis in wheat. Indian Res J Genet Biotec 5(3):197-202.

12. Ijaz U \& Samiullah (2103). Heritability estimates of physiological and yield components in bread wheat under rainfed condition. Int J Mod Agric 2(2).
13. Jan S, Mohammad F \& Khan FU (2015). Genetic potential and heritability estimate of yield traits in F3 segregating population of bread wheat. Int $J$ Environment 4(2): 20912854.

14. Kumar N, Markar S \& Kumar V (2014). Studies on heritability and genetic advance estimates in timely sown bread wheat. Bio Sci Discovery, 5(1): 64:69.

15. Khalid M, Khalil IH, Farhatullah, Bari A, Tahir M, Ali S, Anwar S, Ali A \& Ismail M (2011). Assessment of heritability estimates for some yield traits in winter wheat. Pak J Bot 43(6): 2733-2736.

16. Baloch MJ, Baloch E, Jatoi WA \& Veesar NF (2013). Correlation and heritability estimates of yield and yield attributing traits in wheat. Pak J Agri Engg Vet Sci 29(2): 96-105 